\title{
Bureaucracy Culture in Public Service in Indonesia
}

\author{
H Agustina ${ }^{1}$ \\ \{heryaniagustina28@gmail.com ${ }^{1}$ \} \\ ${ }^{1}$ Universitas Swadaya Gunung Djati, Indonesia
}

\begin{abstract}
Indonesian government bureaucracy culture is formed through the long historical process started from traditional kingdom era patrimonial bureaucracy, Dutch colonial era colonial bureaucracy, Japanese colonial era, independent revolutionary era, until now modern bureaucracy. Those traditions from traditional kingdom era, colonial-era until now strengthen and the continuation from the previous era. Historically, bureaucracy in Indonesia has no tradition to put public service as center of bureaucracy life. Since colonial era until now, public service is always in marginal position. Priyayi mentality that wants to be served is still adopted by bureaucracy apparatus in giving public service. The solution is doing bureaucracy reformation that focuses on mindset and culture set of bureaucracy apparatus through National Mental Revolution Movement. But, bureaucracy reformation faces many challenges from the bureaucracy body itself.form. Therefore, it was not formulated to overcome certain events only.
\end{abstract}

Keywords: bureaucracy culture, public service, bureaucracy reformation

\section{Introduction}

The opening of 1945 Constitution of Indonesia Republic paragraphs four states that Indonesian country goal is to protect all Indonesian people and soil, to improve public prosperity, and to keep world peace based on independence, peacefulness, and social justice. That Indonesian country goal becomes the government duty that is implemented by giving public service.

Public service in Indonesia in a new era of regional autonomy is more important because it becomes regional government goal as stated in Law Number 22 the Year 1999 on Regional Government that has changed into Law Number 32 Year 2004 and Law Number 23 Year 2014 According to Law Number 23 the Year 2014, regional government practice is directed to accelerate the implementation of society prosperity through service improvement, enforcement, and social participation, and regional competitive improvement by showing democracy principle, equality, justice and regional specialty in Indonesian Country system. That is why public service improvement is one of the ways to accelerate the implementation of public prosperity that becomes the goal and spirit of regional autonomy.

In order to improve public service, Law Number 25 the Year 2009 on Public Service has been decided. The goal of that Law decision are:

a. Implementation of clear limitation and relationship about rights, responsibility, duty, and authority of all parties related to the implementation of public service.

b. Implementation of a public service system that proper with governmental public principles and good coordination. 
c. Fulfillment of public service implementation suitable with rules of law.

d. Implementation of protection and legal assurance for society in public service implementation.

Along with that, the government has done many efforts of public service through many service patterns that are one door or one roof integrated service, online service, and electronic service. Society has felt the benefit of those service pattern. But on the other side, society often complains about public service such as slow service, complex service procedure, unresponsive officer in handling society complain, expensive service cost, discriminative treatment in service, officer mentality who wants to be served not serving society, etc.

This paper will discuss the bureaucracy culture in public service in Indonesia with its solution and challenge. The discussion of bureaucracy culture in public-serving will be traced from the origin of public service in Indonesia from kingdom era and colonial era until now.

\section{Method}

In order to get the data for this paper, the research is done using a qualitative approach. Qualitative research is a method to explore and understand the meaning ---that by some individuals and groups is considered coming from social or humanity problems [1]. The data in this research is collected from literature study by learning various relevant literature, in the form of books, rules of law, or data from the internet.

\section{Result and Discussion}

\subsection{Organization Culture Concept}

Every organization has an organizational culture that differentiates that organization from other organization. According to Stoner [2], organization culture is a set of values, norm, attitude and faith that are believed by all members of the organization. Robbins [3] states that four functions of organizational culture are:

a. Culture has a role to set a limit.

b. Culture means identity for an organization.

c. Culture facilitates commitment.

d. Culture increases social system stability.

While Siagian [4] states five important functions of organization culture, that are:

a. As the indicator of attitude limits, deciding what could or could not be done, what thing are considered good or bad, deciding what is right or wrong.

b. Creating an identity of an organization and its member.

c. Creating commitment to common interest above individual or group interest.

d. As the binding rope for all organization members.

e. As the control device of the attitude of the organization members.

In an organization culture context, there are strong culture and weak culture terms. Strong culture is values that are held intensively and commonly believed in an organization. Weak culture is values that are not supported by the organization members or forced, so it brings negative effect to the organization because the organization will give the wrong direction to its member Suwarto and Koeshartono[2]; Ndraha[5].

Those values in organization culture then stated in motto or slogan of working culture, such as: "professionalism", "integrity", "commitment", "dedication", "loyalty", "discipline", "responsive", "responsibility", "transparency", "quality first", "customer first", "give the best service", "serve with heart", "friendly", etc. Those values then implemented in attitude of 
management/organization in daily implementation of organization. This is supported by Ndraha [5] that values in organization culture will create management/organization attitude.

In the organization that has a strong culture, values embraced by the organization do not only become motto, slogan or theory but it was believed by all member of the organization and it becomes the foundation of their attitude. Those values implementation is done through socialization process and internalization in organization since someone become member of organization. On the other hand, organization that has weak culture, the values believed by the organization only become motto, slogan, or theory that the implementation is "the grill is far from the fire".

In an organization that has a strong culture, the attitude of the organization member is suitable with the values in the organization. While in organization that has weak culture, the attitude of organization member is not suitable with values in the organization. The attitude of the organization member can be seen and felt clearly by the customer when they get the service from the member.

The attitude of organization member will create organization character because attitude shows character. Organization character is organization nature that is formed from values, moral and norm that become the foundation of point of view, thinking, attitude, and the way of the organization member act that differentiate one organization with other organization. Strong organization culture creates strong organization character, while weak organization culture will create weak organization character.

\subsection{Public Service Concept}

Human, as long as they live, always needs public service from the government. When they were born, human needed service such as a birth certificate. Then during their life, human needs many services such as education, health, population and civil registration, various permit, etc. Even when they are dead, human still needs burial service and death certificate. The existence and role of government as the one who gives service is important, even though there are many public services done by private sector.

According to Kotler [6], service is every beneficial activity in a group and offer satisfaction, although the result is not physically bound to a certain product. While according to Moenir [7], service is an activity done by someone or group or organization with material factor foundation through certain system, procedure, and method in order to fulfill other person interest according to his/her rights.

Public service is a service given to the public or society. According to Law Number 25 Year 2009 on Public Service, society in public service context is all parties, citizen or individual, group or legal institution that receive the benefit of public service, directly or indirectly.

Public service is serving people or society need who has an interest in the organization suitable with decided main rules and regulation [8]. Public service is every activity done by the government to certain number of people who has every beneficial activity in a group an offer satisfaction, although the result is not physically bound to certain product [9].

Public service is public service and product availability, done by the government or nongovernment party [9]. That is why public service also can be done by non-government parties. This is suitable with Law Number 25 the Year 2009 that public service is activity or series of was in order to fulfill service needs suitable with rules of law for every citizen and people of products, service, and/or administrative service provided by public service provider. The public service provider is every government practitioner institution, cooperation, independent 
institution that is formed based on law for public service, and other legal institution formed only for public service.

According to Law Number 25 the Year 2009, public service is held based on public interest, legal assurance, equality of rights, rights and duty balance, professionalism, participative, equal treatment/non discriminative, openness, accountability, facility, and special treatment for vulnerable group, timeliness, speed, ease and affordability. Public service covers all service needed by society in their life. Public service consists of three types, namely product service, services, and administrative service.

According to Minister of State Apparatus Empowerment Decree Number 63/KEP/M.PAN/2003, public service is done using three patterns namely functional, centered, and integrated service. Functional service is public service pattern by service provider suitable with duty, function, and authority. Centered service is service pattern given solely by the service provider based on authority delegation from service provider related to others. While integrated service consists of three patterns namely, one roof-integrated, one door integrated and working group. Whatever service pattern implemented, public service wanted by society is qualified to serve.

According to Garvin [10], quality in service is a dynamic condition related to the product, human labor, process and duty, and environment that fulfill or beyond customer or consumer expectation. The same thing is also stated by Tjiptono and Diana [11] that service quality is a dynamic condition related to service, human, process, and environment that fulfill the expectation. Service quality is a dynamic condition because service quality given can change from time to time.

Zeithaml [12] states that service quality consists of ten dimensions, namely tangible, reliable, responsiveness, competence, courtesy, credibility, secure, access, communication and understanding the customer. Those ten service quality can be resumed into five dimensions, that are:

a. Tangible consists of indicators: officer performance in serving customer, serving place comfort, easiness in serving process, officer discipline in giving the service, easiness of customer access in application service, and the use of helping aids in service.

b. Reliability consists of indicators: officer carefulness in serving customer, having clear standard service, officer ability in using helping aids in serving process, officer skill in using helping aids in serving process.

c. Responsiveness consists of indicators: response every customer who wants to get service, the officer does the service fast, effectively and with an exact time, and all customer complains are responded by officer.

d. Assurance consists of indicators: officer gives a guarantee of on-time service, cost guarantee in service, legality guarantee in service, and cost certainty guarantee in service.

e. Empathy consists of indicators: prioritize customer needs, officer serves friendly, politeness, non-discriminative, and respect customer.

According to Komarudin [13], success measurement of service practice is decided by the satisfaction level of the service recipient. If the service is given is as expected or beyond society expectation, society will be very satisfied. In contrast, if the service given is not as expected or does not fulfill society expectation, society will not be satisfied. This service recipient satisfaction is reached if the recipient gets service as needed and expected. 


\subsection{Bureaucracy Culture in Public Service in Indonesia}

Reformation era in Indonesia started after the fall of Soeharto regime on May 21, 1998. Reformation has six reformation agenda, namely, administer justice to Soeharto and his friends, 1945 Constitution amendment, erasing Indonesian Military Forces dual function, broad regional autonomy practice, legal supremacy enforcement, and create the government that is free from Collusion, Corruption and Nepotism CCN.

Reformation also happened in government bureaucracy area. In bureaucracy reformation, the Indonesian government has issued Presidential Regulation Number 81 the Year 2010 on Grand Design of Bureaucracy Reformation 2010-2025 that described into a road map of bureaucracy reformation 2010-2014 and 2015-2019 that decided in Minister of State Apparatus Empowerment Regulation. In those bureaucracy reformation grand design and road map, it is decided three targets of bureaucracy reformation in Indonesia that are implementation of government that is clear from $\mathrm{CCN}$, improving public service quality to society, and improving capacity and accountability of bureaucracy work. The changing area in bureaucracy reformation covers organization, regulation, rules of law, apparatus source, supervision, accountability, public service, and mindset and culture set.

Public service quality improvement is one of the target and area of bureaucracy reformation changing in Indonesia. Many efforts have been done by the Indonesian government to improve public service quality through bureaucracy reformation by issued many regulations, simplifying service procedure, deciding Minimum Standard Service MSS, implementation of one roof and one door service pattern, implementation of online and electronic service, etc. But the result of research conducted by Dwiyanto [14] shows that public service in Indonesia in reformation era has not changed significantly. Society often complains about public services, such as slow service, complicated service procedure, unresponsive officer in handling society complain, officer mentality who wants to be served, not serving society, etc.

If we see carefully, the weaknesses in public service in Indonesia recently is resulted in mindset, culture set, mentality, attitude, and behavior of apparatus in giving public service. If we learn more, bureaucracy culture in public service cannot be separated from the historical root since traditional kingdom era in Indonesia. As stated by Santoso [15], bureaucracy culture of Indonesian government is formed through long historical process, started from traditional kingdom era and continued to Dutch colonial era, Japanese colonial era, independence revolution era, until now. A tradition from the traditional kingdom era, colonial-era until now basically strengthen each other and is continuation from the previous era.

In traditional kingdom area patrimonial bureaucracy, kingdom bureaucracy was held by abdi dalem. A king through his bureaucracy that is abdi dalem command his people. By the king, that abdi dalem are given the rights of the land, taking tax from people without clear limitation and regulation, that is given to the king later after they took their portion. That $a b d i$ dalem later developed into social class that separated from general society class. That patrimonial bureaucracy system cause the bureaucracy position is only the representatives of king authority. The practice of territorial power, tax, court, security, and religious, is more authoritative than service Kunto Wijoyo in Santoso, 1995. Kingdom bureaucracy was formed to serve king and his family needs, not to serve society. Kingdom bureaucracy is king's servant, not society's servant, so the orientation is not serving and making society prosperous, but serving and making the king and his family prosperous [14].

When traditional kingdom era in Indonesia ended, Dutch colonial government pointed officials from their own country as colonial bureaucracy officials. In some areas the 
bureaucracy officials are fully held by colonial government and in some other areas are implementing a double government that besides colonial bureaucracy, there was also traditional bureaucracy. Generally native people appointed in colonial bureaucracy staff is priyayi. Priyayi has position as ambtenaar pangreh praja is priyayi that has strong position in society [15]. The bureaucracy of this ambtenaar sociologically included into penggedhe group that in social relationship tend to consider as "master" by kawulo that consist of common people.

The colonial government built bureaucracy into a legal-rational model which is bureaucracy with an orientation of discipline, honest, and respect the law known as beambtenstaat. Beambtenstaat was efficient bureaucracy machine, neat, strong focus on administration, technical skill, and economic development, so beambtenstaat in 1900-1942 period is the best bureaucracy in Indonesian history Castles in Santoso, 1995. But the success of bureaucracy reformation in the form of beambtenstaat did not change pangreh praja character because the thing changed is only the relationship between pangreh praja with colonial authority, while in its structure---especially in its relationship with native people--still in patrimonial condition.

Based on the explanation above, culture believed in patrimonial bureaucracy in traditional kingdom era in Indonesia was prioritize service to the king, not public service. This is reflected from abdi dalem term that means the maid or king servant, not the maid or public servant. In a patrimonial bureaucracy, it was hard or impossible to expect public service because bureaucracy apparatus abdi dalem was king servant. Besidess that, abdi dalem were in high social class in society, so they demand to be served and respected by society.

Then in the colonial government era, bureaucracy mostly held by priyayi. Priyayi mentality was not so different from abdi dalem because priyayi were also the representative of colonial government. Priyayi were native people who have high social class that was usually respected and served by a society that was kawulo common people. That is why, like abdi dalem, priyayi orientation service was not to society but to colonial government because priyayi were abdi dalem of colonial government.

Patrimonial bureaucracy culture that is legacy from traditional kingdom era and priyayi bureaucracy that is legacy from the colonial era, implemented during new order era [15]. Javanese authority concept has colored the authority of new order government. Indonesian bureaucracy attitude basically rooted from traditional culture custom of palace and kingdom in Java, still bring some of those values until now. Indonesian bureaucracy model that comes from tradition, especially the one rooted from traditional Javanese kingdoms, tend to strengthen each other with values of colonial legacy [16].

When the reformation era happened, the mentality of patrimonial bureaucracy and priyayi bureaucracy did not change much. In reformation era, mentality of abdi dalem and priyayi is still believed by official and bureaucracy apparatus. This is shown in public service where official and bureaucracy apparatus still put themselves as pangreh praja who demand to be respected and served by society, not as pamong praja who serve society. With many reasons, official and bureaucracy apparatus often make the service slow and at the end ask for money, so they know the slogan "if the service can be made harder, why make it easier?" Public service reformation in the form of one door service still inhibited by bad mentality of the apparatus. Even though the service has been done in one door, but the service still can be done through "back door", so the slogan "one door service but with many windows" appear.

Apparatus mentality and attitude that complicate service cause the most sophisticated service is not useful. Online and electronic service that should reduce bureaucracy is also wasted if the apparatus still has a mentality and attitude to complicate service. One of the 
examples is in September 2016 when Risma Mayor of Surabaya did the unexpected supervision and get angry in Civil Registration Office Surabaya because of the service of EKTP electronic ID card that can be faster become more difficult, slower and complicated [17].

\subsection{Solution and Challenge}

The mentality of abdi dalem and priyayi that is still believed in bureaucracy body in the reformation era is ironic because reformation era should be followed by basic changes in bureaucracy apparatus mentality. Government has done bureaucracy reformation in many ways, but it has not shown the best result. Why does all this happen?

Historically, bureaucracy in Indonesia does not have a tradition to put society interest as the center in bureaucracy life. Since the colonial era until new order era, society interest is always in marginal position. Non-democratic political system during new order era is also weakened society bargain position in facing the government and the bureaucracy. Political control also did not run well because the base and source of authority during new order era tend to focus on government and its bureaucracy [14]. Attitude and classical way that never change until now in giving public service is government apparatus and official arrogance. The service given always oriented from official, authoritative and government interest, not based on desire and needs of served society [18].

Bureaucracy reformation is seen as the best way to change bureaucracy culture in public service. According to Tamin [19], generally bureaucracy reformation is reforming on being reformed; the effort for legal enforcement and constitution; a change for better in morals, habits, methods, public sector reform in the effort of creating good governance and clean government, means for creating modern, democratic, and multicultural society; improvement and forming something new; unstopping perfection, etc. Bureaucracy reformation must be done continuously and simultaneously in six work that covers evaluation, regulation, control, improvement, perfection, and renewal. Bureaucracy reformation object is all state practicing sector in governmental area institution, human resources apparatus, regulation, accountability, and public service. Bureaucracy reformation process is really done based on principle and existed rules of law, at least there are four targets which are related to system, policy, rules of law, and moral personality.

Turner \& Hulme [20] states that bureaucracy reformation can be done through five strategies which are restructuring, participation, human resources issue, accountability, and combination of the public and private sector. But, according to Champy [18], reformation and changes in government mostly stop in restructuring, reorganizing, and reengineering. Restructuring and reorganizing can be done through new institutions establishment, erasing institution, and institution merger, in local or center level.

According to the writer, bureaucracy reformation in Indonesia is only in "the skin" not in "the body" of bureaucracy. Bureaucracy reformation program only changes the face of bureaucracy but it is not able to change values in the form of mindset and culture set of bureaucracy apparatus. In this case, National Mental Revolution Movement that is proclaimed by President Jokowidodo at the end of 2014 can become the solution to change mindset and culture set of bureaucracy apparatus. National Mental Revolution Movement covers three targets:

a. Change of mindset and paradigm of government apparatus from priyayi bureaucracy to the bureaucracy that serves society.

b. Government organization structure must be slim, efficient, and does not duplicate function. 
c. Change of working set culture that is more disciplined, responsible, and prioritize togetherness and cooperation.

It seems that one of the targets of the National Mental Revolution Movement is the change of mindset and point of view of government apparatus from priyayi bureaucracy to bureaucracy that serves society. But the movement has not shown the great result yet, because priyayi mentality is still believed in bureaucracy institution of Indonesian government. This movement is streaked by corruption case of state officials in central area. While in regional area, more than half of local head in Indonesia are involved in corruption case.

National Mental Revolution Movement target must be targeted to society as the served party because society---realized or not---get involved in preserving priyayi mentality in bureaucracy institution. Apparatus mentality who wants to be served and intentionally make service difficult with the hope that society will give certain reward suitable with the society who wants to be served quickly. Koentjaraningrat [21] states that society mentality with the term "bypass mentality" is a colonial legacy that wants to finish all the business fast, so they do all they need, including give a bribe to apparatus.

National Mental Revolution Movement proclaimed by Jokowi is bureaucracy reformation policy that is efficient to erase priyayi mentality in bureaucracy institution. But, this mental revolution will face big challenge because priyayi mentality has become a bureaucracy culture in Indonesia for a long time. The biggest challenge comes from the internal of bureaucracy itself because the mental revolution will disturb comfort zone of much official and bureaucracy apparatus who have priyayi mentality. They, of course, will keep status quo and do not want to change because the change is a threat to their comfort zone. That is why, reformation and mental change cannot be done in short time or revolutionarily, but it must be done according to the plan, program, in stages, continuously, consequently, and consistently.

To create a mental revolution, strong commitment and political will are not enough, but it must be followed by political action in the form of leader example, firm and bereavement, concrete mental revolution programs, and non-discrimination legal enforcement. Besides that, mental revolution as a national movement must be supported by all nation components because a national movement demands participation from all parties. Mental education and character education must be held in formal education level start from early education until higher education to prepare students as the candidate of national leader who has good mental.

\section{Conclusion}

Government main duty is giving public service. Public service becomes the duty of government as a public service provider and becomes the rights of public society as the party that is served. Professional bureaucracy in giving qualified public service is all parties expectation. But that expectation is inhibited by priyayi bureaucracy culture that is believed in bureaucracy institution in Indonesia.

Priyayi bureaucracy culture in Indonesia is formed through a long historical process, starting from the traditional kingdom era patrimonial bureaucracy, Dutch colonial era, Japanese colonial era, independence revolution era, until now modern bureaucracy. A tradition from traditional kingdom era, colonial-era until now basically strengthen and is a continuation from the previous era. Historically bureaucracy in Indonesia does not have tradition to put public service as the center in bureaucracy life. Since colonial era until now, society interest is always in marginal position. Priyayi mentality is still believed by bureaucracy apparatus in giving public service. The solution is doing bureaucracy reformation that focuses on mindset 
and culture set of bureaucracy apparatus through National Mental Revolution Movement, but bureaucracy reformation faces challenge from the internal of bureaucracy institution itself.

\section{References}

[1] J. W. Cresswell, Research Design. Pendekatan Kualitatif, Kuantitatif, dan Mixed. Yogyakarta: Pustaka Pelajar, 2014.

[2] F. X. dan D. K. Suwarto, Budaya Organisasi: Kajian Konsep dan Implementasi. Yogyakarta: Universitas Atma Jaya, 2009.

[3] S. P. Robbins, Teori Organisasi, Struktur, Desain dan Aplikasi. Jakarta: Arcan, 1994.

[4] S. P. Siagian, Organisasi, Kepemimpinan dan Perilaku Administrasi. Jakarta: Haji Masagung, 1999.

[5] T. Ndraha, Teori Budaya Organisasi. Jakarta: Rineka Cipta, 2005.

[6] S. Lukman, Manajemen Kualitas Pelayanan. Jakarta: STIA LAN Press, 2000.

[7] A. S. Moenir, Manajemen Pelayanan Umum di Indonesia. Jakarta: PT.Bumi Aksara, 2006.

[8] A. Kurniawan, Transformasi Pelayanan Publik. Yogyakarta: Pembaruan, 2005.

[9] dkk Sinambela Lijan Poltak, Reformasi Pelayanan Publik: Teori, Kebijakan dan Implementasi. Jakarta: Bumi Aksara, 2014.

[10] M. N. Nasution, Manajemen Mutu Terpadu (Total Quality Management). Jakarta: Ghalia Indonesia, 2000.

[11] F. \& A. D. Tjiptono, Total Quality Management. Yogyakarta: Andi, 2001.

[12] Herdiyansyah, Kualitas Pelayanan Publik: Konsep, Dimensi, Indikator dan Implementasinya. Yogyakarta: Gava Media, 2011.

[13] Komarudin, Reformasi Birokrasi dan Pelayanan Publik. Jakarta: Genesindo, 2014.

[14] dkk Dwiyanto Agus, Reformasi Birokrasi Publik di Indonesia. Yogyakarta: Gadjah Mada University Press, 2006.

[15] P. B. Santoso, Birokrasi Pemerintah Orde Baru. Jakarta: Raja Grafindo Persada, 1995.

[16] A. Setiawan, Perilaku Birokrasi Dalam Pengaruh Paham Kekuasaan Jawa. Yogyakarta: Pustaka Pelajar, 1998.

[17] Kompas, "Ketika Risma mengamuk di kantor disdukcapil kota Surabaya," 2016. .

[18] Thoha, Birokrasi Pemerintah dan Kekuasaan di Indonesia. Yogyakarta: Thafa Media, 2012.

[19] F. Tamin, Ilmu Administrasi Publik Kontemporer. Jakarta: Kencana Prenadamedia Group, 2004.

[20] M. Turner and D. Hulme, Governance, Administration \& Development. Making The State Work. Connecticut: Kumarian Press, 1996.

[21] Koentjaraningrat, Kebudayaan, Mentalitas dan Pembangunan. Jakarta: PT Gramedia Pustaka Utama, 2015. 